\title{
DIARRHEIC SYNDROME IN BROILER AND SOME WILD BIRDS CAUSED BY ESCHERICHIA COLI
}

\author{
GHADA, O. EL-DEMERDASH ${ }^{1}$; FATMA AMER ${ }^{2}$ AND HEBA ROSHDY ${ }^{2}$ \\ ${ }^{1}$ Animal Health Research Institute, Fayoum Branch, Agriculture Researches Center, Egypt \\ ${ }^{2}$ Reference Laboratory for Veterinary Quality Control on Poultry Production, Animal Health \\ Research Institute, Ministry of Agriculture, P.O. Box 246 - Dokki, 12618 - Giza, Egypt
}

Received: 13 March 2021; Accepted: 30 March 2021

\begin{abstract}
E. coli is a Gram negative bacterium, although it is normal intestinal inhabitant but some strains due to their virulence genes play a major role in causing diarrhea in birds. In the present study, a total of 150 fecal swabs from (crows, egret wild birds and broiler chicken) collected from Giza, Fayoum city governorates, (50 each). The result showed, that isolation rate of E.coli was reported to be isolated in higher incidence in Fayoum governorate from crows, $48 \%$, broiler chicken, $40 \%$ and egret wild birds $28 \%$ while Giza Governorate in where E.coli was isolated from crows, egret wild birds and broiler chicken ,an incidence of $20 \%, 12 \%$ and $20 \%$ respectively. The serogroups of E. coli strains that obtained by serological identification were from crows (O78, O91, O145, O127, O158, O119, O125 and O55), egret bird (O78, O158, O125, O119, O91 and O44) and chicken broiler (O78, O125 and O158). The results of sensitivity test for some E. coli isolates showed that they were highly resistant for to streptomycin $(83.4 \% 66.4 \%$ and $42.8 \%)$ in (crows, egret birds and broiler chicken) respectively. The results of multiplex PCR showed that phoA, virulence gene was detected in all E.coli serogroups while, Stx2, gene was detected in serogroups O78, O91 and O125 in crows only. (hly, eaeA and Stxl) virulence genes were not detected in all tested E. coli sergroups. On the other hand aadAl gene was detected by some E. coli strains (7from crows and 2 from egret).
\end{abstract}

Keywords: broilers chicken, E. coli, resistant genes, and antimicrobial resistance, Wild birds.

\section{INTRODUCTION}

Wild birds is important vectors and reservoirs for fecal pathogens in coastal areas. As vectors of many diseases has taken big interest recently, Also these birds have migratory behavior causes dissemination of multi- resistant (MR) bacteria through

Corresponding author: Heba Roshdy

E-mail address: roshdy2019 @yahoo.com

Present address: Reference Laboratory for Veterinary Quality Control on Poultry Production, Animal Health Research Institute, Ministry of Agriculture, P.O. Box 246 - Dokki, 12618 - Giza, Egypt colonized or infected with resistant bacteria (Guenther et al., 2011; Oteo 2018; Arnold et $a l ., 2016)$. From bad habits of human help in attracted wild birds to garbage, manure, untreated sewage so those birds carry many pathogens like Salmonella enterica E.coli, and Campylobacter spp (Moore et al., 2002; Fogarty et al., 2003; Waldenström et al., 2003) E.coli The importance as that it found in food, and environment it also harm animal and human as it is opportunistic bacteria (Benskin et al., 2009; Lisa et al., 2013). 
The nature of life of crows and egret birds as one of wild birds which living near villages and towns, it disseminate E.coli through feases to the environment causes spread of infection to animals, birds, human through biological or mechanical way (Clark, 2003; Hbalck, 2004; Mbanga et al., 2015) especial if its aggregation is found near the domestic rearing which causes many economic losses through dissemination of pathogens and also act as carrier and transporter to infection between animals birds and human (Ishii et al., 2007; Maysa et al., 2013). Also its droppings contain nutrient matters that attracts flies which help in transfere microorganisms (Johnson et al., 2007). Recent studies have Proved that wild bird and rooks shedding bacteria which resistant to antibiotics (Hasan et al., 2015; Jamborova et al., 2017; Keya et al., 2019). The molecular differentiation of different $E$. coli strains could give guidance for epidemiological studies of sources of infection and disease transmission. A random amplified polymorphic DNA polymerase chain reaction (RAPD-PCR) is quicker and more effective procedure to differentiate variant isolates of $E$. coli. The distinctive DNA patterns generated by RAPD for each E. coli isolate reflects genetic diversity present in a bird species (Gomes et al., 2005). The aim of this present work was to characterize and investigate the Prevalence and characterize the E. coli isolates from crows, egret birds and broilers chicken (serologically, biochemically, detection of antimicrobial sensitivity to different antimicrobial agents, and detection of some virulence genes of E.coli using PCR technique, and detection of some antibiotic resistance genes in E. coli isolates by PCR technique.

\section{MATERIALS AND METHODS}

\section{Samples Collection and Preparation:}

A total of 150 fecal swabs were collected from crows, egret birds and diarrhatic fecal swabs from broiler chicken (50 each) and submitted to the Central Laboratory for
Veterinary Quality Control on Poultry Production, Dokki and Fayoum to be checked for the presence of $E$. coli infection. The samples were collected from (Giza, Fayoum) governorates. All samples were collected without any contamination by sterile cotton swabs then inoculated in test tube then rapidly transported in ice box to the laboratory. According to (Middleton et al., 2005).

\section{Bacteriological examination:}

All samples were examined bacteriologically for the presence of E.coli. Isolation and identification of E.coli were done according to (Lee et al., 2008). Where, all the collected samples were pre-enriched in buffered peptone water (Oxoid) and incubated at $37^{\circ} \mathrm{C}$ for $24 \mathrm{hrs}$ under aerobic conditions. Then a loop ful from each broth culture was inoculated onto blood agar, MacConkeys' agar (Oxiod), XLD agar (Oxiod) and Eosin methylene blue agar plates (Oxiod) and incubated at $37^{\circ} \mathrm{C}$ for 24 hours. The growing surface colonies were picked up, surfaced and further biochemically tested for growth on triple sugar iron agar and lysine iron agar, citrate utilization, urease production, and indole fermentation were done.

\section{Serotyping of $E$. coli isolates:}

E.coli isolates were serotyped by slide agglutination test according to (Lee et al., 2009) using standard E. coli antisera (Sifin and Denka Seiken Comp.).

\section{Antibiotic sensitivity tests:}

The antibiogram of some $E$. coli isolates was done by disc-diffusion method according to (Koneman et al., 1997) against (ten) antimicrobials $\left(\right.$ Oxoid $^{\circledR}$ ), and the zones of inhibition were measured and interpreted according to the Clinical and Laboratory Standards Institute (CLSI) guidelines (CLSI/NCCLS, 2017). The used antibiotics were Amoxicllin+ Clavulanic acid $(\mathrm{Am}+\mathrm{CL}$, 20-10 $\mu \mathrm{g})$, Chloramphenicol $\left(\mathrm{C}^{30}, 30 \mu \mathrm{g}\right)$, Ciprofloxacin $\left(\mathrm{CF}^{5}, 5 \mu \mathrm{g}\right)$, Gentamicin $\left(\mathrm{G}^{10}\right.$, $10 \mu \mathrm{g})$, Nalidixic acid $\left(\mathrm{NA}^{30}, 30 \mu \mathrm{g}\right)$, Nitrofurantoin $\left(\mathrm{F}^{300}, 300 \mu \mathrm{g}\right)$, Norfloxacin $\left(\mathrm{NX}^{10}, \quad 10 \mu \mathrm{g}\right), \quad$ Trimethoprim- 
sulfamethoxazole

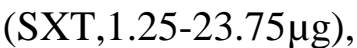
Tetracycline $\left(\mathrm{T}^{30}, 30 \mu \mathrm{g}\right)$ and Streptomycin $\left(\mathrm{S}^{10,} 10 \mu \mathrm{g}\right)$.

\section{Detection of virulence and antibiotic resistance genes in some $E$. coli isolates by PCR technique:}

\subsection{Extraction:}

DNA of enriched isolates was extracted using commercially available kit, QIAamp DNA Mini Kit, Catalogue no.51304.

\subsection{Amplification}

Pho-sxt1-sxt2-hyl-eae genes amplification were amplified according to references mentioned in Table (1).

\subsection{Analysis of the PCR Products}

The products of PCR were separated by electrophoresis on $1 \%$ agarose gel (Applichem, Germany, GmbH) in 1x TBE buffer at room temperature using gradients of $5 \mathrm{~V} / \mathrm{cm}$. For gel analysis, $15 \mu \mathrm{l}$ of the PCR products were loaded in each gel slot. A 100 bp and 100 bp plus DNA Ladder (Qiagen, Germany, GmbH) were used to determine the fragment sizes. The gel was photographed by a gel documentation system (Alpha Innotech, Biometra) and the data was analyzed through computer software.

Table 1: Oligonucleotide primers sequences used for amplification of DNA for the detection of E. coli.

\begin{tabular}{|c|c|c|c|c|}
\hline $\begin{array}{l}\text { Target } \\
\text { gene }\end{array}$ & Primers sequences & $\begin{array}{c}\text { Amplified } \\
\text { fragment (bp) }\end{array}$ & Annealing & References \\
\hline phoA & $\begin{array}{l}\text { CGATTCTGGAAATGGCAAAAG } \\
\text { CGTGATCAGCGGTGACTATGAC }\end{array}$ & 720 & $\begin{array}{l}55^{\circ} \mathrm{C} \\
45 \mathrm{sec}\end{array}$ & $\begin{array}{l}\text { Hu et al. } \\
2011\end{array}$ \\
\hline hly & $\begin{array}{l}\text { AACAAGGATAAGCACTGTTCTGGCT } \\
\text { ACCATATAAGCGGTCATTCCCGTCA }\end{array}$ & 1177 & $\begin{array}{l}60^{\circ} \mathrm{C} \\
50 \mathrm{sec} .\end{array}$ & $\begin{array}{l}\text { Piva et al., } \\
2003\end{array}$ \\
\hline eaeA & $\begin{array}{l}\text { ATGCTTAGTGCTGGTTTAGG } \\
\text { GCCTTCATCATTTCGCTTTC }\end{array}$ & 248 & $\begin{aligned} 51^{\circ} \mathrm{C} \\
30 \mathrm{sec}\end{aligned}$ & $\begin{array}{c}\text { Bisi-Johnson } \\
\text { et al., } 2011\end{array}$ \\
\hline Stx 1 & $\begin{array}{l}\text { ACACTGGATGATCTCAGTGG } \\
\text { CTGAATCCCCCTCCATTATG }\end{array}$ & 614 & $\begin{array}{l}58^{\circ} \mathrm{C} \\
40 \mathrm{sec} .\end{array}$ & \\
\hline Stx 2 & $\begin{array}{l}\text { CCATGACAACGGACAGCAGTT } \\
\text { CCTGTCAACTGAGCAGCACTTTG }\end{array}$ & 779 & $\begin{array}{c}58^{\circ} \mathrm{C} \\
40 \mathrm{sec} .\end{array}$ & $\begin{array}{l}\text { Dipineto et } \\
\text { al., } 2006\end{array}$ \\
\hline $\operatorname{aadA1}$ & $\begin{array}{c}\text { TATCAGAGGTAGTTGGCGTCAT } \\
\text { GTTCCATAGCGTTAAGGTTTCATT }\end{array}$ & 484 & $\begin{array}{l}54^{\circ} \mathrm{C} \\
40 \mathrm{sec}\end{array}$ & $\begin{array}{l}\text { Randall et al. } \\
2004\end{array}$ \\
\hline
\end{tabular}

phoA: Alkaline phosphatase. hly: alpha-haemolysine. eaeA: Attachment and Effacement, Stx1: shiga- toxin 1, Stx2: shiga-toxin 2. aadA1: (aminoglycoside 3"-adenylyltransferase activity antibiotic resistance genes).

\section{RESULTS}

1. Isolation rate of E.coli recovered from crows, egret wild birds and chicken broiler feces in different governorates: The isolation rates of E.coli were reported to be higher in Fayoum Governorate in (crows, 48\%, broiler chicken, $40 \%$ and egret wild birds $28 \%$ ) than Giza Governorate were E.coli was isolated from crows, egret wild birds and broiler chicken is an incidence of $20 \%, 12 \%$ and $20 \%$ respectively.

Table 2: Isolation rates of E.coli recovered from crows, egret birds and Chicken broiler samples in different governorates.

\begin{tabular}{|c|c|c|c|c|c|c|c|c|c|c|c|c|}
\hline \multirow{2}{*}{ Locality } & \multicolumn{3}{|c|}{ Crows feces } & \multicolumn{3}{|c|}{ Egret feces } & \multicolumn{3}{|c|}{ Chicken broiler feces } & \multicolumn{3}{|c|}{ Total } \\
\hline & NO & $+v e$ & $\%$ & NO & $+\mathrm{ve}$ & $\%$ & NO & $+\mathrm{ve}$ & $\%$ & NO & $+\mathrm{ve}$ & $\%$ \\
\hline Fayoum & 25 & 12 & 48 & 25 & 7 & 28 & 25 & 10 & 40 & 75 & 29 & 38.6 \\
\hline Giza & 25 & 5 & 20 & 25 & 3 & 12 & 25 & 5 & 20 & 75 & 13 & 17.3 \\
\hline Total & 50 & 17 & 34 & 50 & 10 & 20 & 50 & 15 & 30 & 150 & 42 & 28 \\
\hline
\end{tabular}

Percentage according to total number of the examined samples in each governorates. 
2. Serotyping Results of $E$. coli isolated from crows feces, egret bird feces and chicken broiler feces:

The most commonly detected E.coli serogroups isolated were from crows $(\mathrm{O} 78$,
O91, O145, O127, O158, O119, O125 and O55), egret bird feces (O78, O158, O125, O119, O91 and O44) and chicken broiler (O78, O125 and O158).

Table 3: The serotypes of $E$. coli isolated from crows feces, egret bird feces and chicken broiler feces:

\begin{tabular}{ccccccc}
\hline \multirow{2}{*}{ serotype } & \multicolumn{2}{c}{ crows feces } & \multicolumn{2}{c}{ egret feces } & \multicolumn{2}{c}{ chicken broiler feces } \\
\cline { 2 - 7 } & No. & $\%$ & No. & $\%$ & No. & $\%$ \\
\hline O78 & 2 & $11.8 \%$ & 1 & $10 \%$ & 3 & $20 \%$ \\
\hline $\mathbf{O 9 1}$ & 2 & $11.8 \%$ & 1 & $10 \%$ & - & - \\
\hline $\mathbf{O 1 4 5}$ & 2 & $11.8 \%$ & - & - & - & - \\
\hline $\mathbf{O 1 2 7}$ & 1 & $5.9 \%$ & - & - & - & - \\
\hline $\mathbf{O 1 5 8}$ & 1 & $5.9 \%$ & 1 & $10 \%$ & 1 & $6.7 \%$ \\
\hline $\mathbf{O 1 2 5}$ & 2 & $11.8 \%$ & 1 & $10 \%$ & 3 & $20 \%$ \\
\hline $\mathbf{O 1 1 9}$ & 1 & $5.9 \%$ & 1 & $10 \%$ & - & - \\
\hline $\mathbf{O 5 5}$ & 1 & $5.9 \%$ & - & - & - & - \\
\hline O44 & - & - & 1 & $10 \%$ & - & - \\
\hline Total serotyped & 12 & $70.6 \%$ & 6 & $60 \%$ & 7 & $46.7 \%$ \\
\hline Un serotyped & 5 & $29.4 \%$ & 4 & $40 \%$ & 8 & $53.3 \%$ \\
\hline Total & 17 & - & 10 & - & 15 & - \\
\hline & & & & & &
\end{tabular}

3. Antimicrobial resistance of E.coli isolated from crows feces, egret wild bird feces and chicken broiler feces:

The results resistance of the testing of E.coli isolates recovered from crows feces, egret feces and chicken broiler feces. Against 10 antimicrobial drugs. It is evident that the highest resistances were recorded against Streptomycin $(83.4 \%, 66.4 \%$ and $42.8 \%$ respectively).

Table 4: Interpretation of antibiotic resistance test of some E.coli isolates.

\begin{tabular}{|c|c|c|c|c|c|c|c|c|c|}
\hline \multirow{2}{*}{ antibiotics } & \multicolumn{3}{|c|}{ Crows feces $N=12$} & \multicolumn{3}{|c|}{ Egret bird feces $N=6$} & \multicolumn{3}{|c|}{ Chicken broiler feces $\mathrm{N}=7$} \\
\hline & $\mathbf{R}$ & $\mathbf{I}$ & $\mathbf{S}$ & $\mathbf{R}$ & $\mathbf{I}$ & $\mathbf{S}$ & $\mathbf{R}$ & $\mathbf{I}$ & $\mathbf{S}$ \\
\hline $\mathrm{Am}+\mathrm{CL}$ & $1(8.3)^{*}$ & $10(83.4)^{*}$ & $1(8.3)^{*}$ & $1(16.6)^{*}$ & $3(50)^{*}$ & $2(33.4)^{*}$ & $2(28.6)^{*}$ & $4(57.1)^{*}$ & $1(14.3)^{*}$ \\
\hline $\mathbf{C}$ & $5(41.7)^{*}$ & $2(16.6)^{*}$ & $5(41.7)^{*}$ & $2(33.3) *$ & $1(16.6)^{*}$ & $3(50)^{*}$ & $2(28.6) *$ & $3(42.8)^{*}$ & $2(28.6) *$ \\
\hline CIP & $2(16.6)^{*}$ & $7(58.4)^{*}$ & $3(25)^{*}$ & $2(33.3)^{*}$ & $3(50)^{*}$ & $1(16.6)^{*}$ & $2(28.6)^{*}$ & $3(42.8)^{*}$ & $2(28.6)^{*}$ \\
\hline GM & $3(25)^{*}$ & $6(50)^{*}$ & $3(25)^{*}$ & $1(16.6)^{*}$ & $4(66.8)^{*}$ & $1(16.6)^{*}$ & $2(28.6)^{*}$ & $2(28.6)^{*}$ & $3(42.8)^{*}$ \\
\hline NA & $6(50)^{*}$ & $2(16.6)^{*}$ & $4(33.3)^{*}$ & $2(33.3)^{*}$ & $3(50)^{*}$ & $1(16.6)^{*}$ & $1(14.3)^{*}$ & $4(57.1)^{*}$ & $2(28.6) *$ \\
\hline $\mathbf{F}$ & $1(8.3)^{*}$ & $9\left(75^{*}\right)$ & $2(16.6)^{*}$ & $1(16.6)^{*}$ & $3(50)^{*}$ & $2(33.4)^{*}$ & $2(28.6)^{*}$ & $3(42.8)^{*}$ & $2(28.6) *$ \\
\hline NX & $1(8.3)^{*}$ & $4(33.3)^{*}$ & $7(58.4)^{*}$ & $2(33.4)^{*}$ & $1(16.6)^{*}$ & $3(50)^{*}$ & $1(14.3)^{*}$ & $2(28.6)^{*}$ & $4(57.1)^{*}$ \\
\hline$S$ & $10(83.4)^{*}$ & $2(16.6)^{*}$ & - & $4(66.8)^{*}$ & $1(16.6)^{*}$ & $1(16.6)^{*}$ & $3(42.8)^{*}$ & $2(28.6)^{*}$ & $2(28.6) *$ \\
\hline SXT & $5(41.7)^{*}$ & $3(25)^{*}$ & $4(33.3)^{*}$ & $1(16.6)^{*}$ & $3(50)^{*}$ & $2(33.4)^{*}$ & $1(14.3)^{*}$ & $4(57.1)^{*}$ & $2(28.6) *$ \\
\hline $\mathbf{T}$ & $6(50)^{*}$ & $2(16.6)^{*}$ & $4(33.3)^{*}$ & $3(50)^{*}$ & $2(33.4)^{*}$ & $1(16.6)^{*}$ & $1(14.3)^{*}$ & $4(57.1)^{*}$ & $2(28.6) *$ \\
\hline
\end{tabular}

$\mathbf{A m}+\mathbf{C L}=$ Amoxicillin + Clavulinic acid, $\mathbf{C}=$ Chloramphenicol, $\mathbf{C I P}=$ Ciprofloxacin, $\mathbf{G M}=$ Gentamicin, $\mathbf{N A}=$ Nalidixic acid, $\mathbf{F}=$ Nitrofurantoin, $\mathbf{N X}=$ Norfloxacin, $\mathbf{S}=$ Streptomycin, SXT $=$ Trimethoprim-sulfamethoxazole, $\mathbf{T}=$ Tetracycline. $*$ (calculated according to the No. of tested E.coli isolates). $\mathbf{R}=$ Resistance, $\mathbf{I}=$ Intermittent, $\mathbf{S}=$ sensitivity. 
4. Detection of virulence genes and antibiotic resistance genes of some E.coli isolated from crows feces, egret wild bird feces and chicken broiler feces by PCR:

To determine the virulence and antibiotic resistance profile of some isolated E.coli on a molecular aspects, PCR was performed for related genes, (phoA, Stx2) virulence genes were detected in tested samples and not detected ( $h l y$ - eaeA and sxtl) virulence genes. On the other hand aadAl antibiotic resistance genes was harbored by some E.coli strains in table (5-6) and photo (1), (2), (3), (4) \& (5).

Table 5: Result of virulence and antibiotic resistance genes of some E.coli isolates.

\begin{tabular}{|c|c|c|c|c|}
\hline strain & serotypes & Source & Virulance genes & $\begin{array}{c}\text { Antibiotic Resistance } \\
\text { genes }\end{array}$ \\
\hline 1 & O55 & crows & phoA & aadAl \\
\hline 2 & O119 & crows & phoA & aadAl \\
\hline 3 & $\mathrm{O} 127$ & crows & phoA & - \\
\hline 4 & $\mathrm{O} 158$ & crows & phoA & aadAl \\
\hline 5 & $\mathrm{O} 78$ & crows & phoA, , Stx 2 & aadAl \\
\hline 6 & $\mathrm{O} 78$ & crows & phoA, , Stx 2 & aadAl \\
\hline 7 & O91 & crows & phoA, , Stx 2 & - \\
\hline 8 & O91 & crows & phoA & - \\
\hline 9 & $\mathrm{O} 145$ & crows & phoA & - \\
\hline 10 & $\mathrm{O} 145$ & crows & phoA & aadAl \\
\hline 11 & $\mathrm{O} 125$ & crows & phoA & aadAl \\
\hline 12 & $\mathrm{O} 125$ & crows & phoA, , Stx 2 & - \\
\hline 1 & $\mathrm{O} 158$ & $\begin{array}{l}\text { chicken } \\
\text { broiler }\end{array}$ & phoA & - \\
\hline 2 & $\mathrm{O} 125$ & $\begin{array}{l}\text { chicken } \\
\text { broiler }\end{array}$ & phoA & - \\
\hline 3 & $\mathrm{O} 125$ & $\begin{array}{c}\text { chicken } \\
\text { broiler }\end{array}$ & phoA & - \\
\hline 4 & $\mathrm{O} 125$ & $\begin{array}{l}\text { chicken } \\
\text { broiler }\end{array}$ & phoA & - \\
\hline 5 & $\mathrm{O} 78$ & $\begin{array}{l}\text { chicken } \\
\text { broiler }\end{array}$ & - & - \\
\hline 6 & $\mathrm{O} 78$ & $\begin{array}{l}\text { chicken } \\
\text { broiler }\end{array}$ & phoA & - \\
\hline 7 & $\mathrm{O} 78$ & $\begin{array}{c}\text { chicken } \\
\text { broiler }\end{array}$ & phoA & - \\
\hline 1 & O119 & egret bird & phoA & - \\
\hline 2 & O78 & egret bird & phoA & aadAl \\
\hline 3 & $\mathrm{O} 125$ & egret bird & phoA & - \\
\hline 4 & O158 & egret bird & phoA & $\overline{a a d A l}$ \\
\hline 5 & O44 & egret bird & - & - \\
\hline 6 & O91 & egret bird & - & - \\
\hline
\end{tabular}

Table 6: Incidences of virulence and antibiotic resistance genes of E.coli isolated from wild birds and broiler chicken by PCR.

\begin{tabular}{cccc}
\hline \multirow{2}{*}{ Examined genes } & \multicolumn{3}{c}{ Source of examined isolate } \\
\cline { 2 - 4 } & crows & egret bird & broiler chicken \\
\hline phoA & $12 \backslash 12(100 \%)$ & $4 \backslash 6(66.6 \%)$ & $6 \backslash 7(85.7)$ \\
\hline Sxt1 & $0 \backslash 12(0 \%)$ & $0 \backslash 6(0 \%)$ & $0 \backslash 7(0 \%)$ \\
\hline Sxt2 & $4 \backslash 12(33.3 \%)$ & $0 \backslash 6(0 \%)$ & $0 \backslash 7(0 \%)$ \\
\hline hly & $0 \backslash 12(0 \%)$ & $0 \backslash 6(0 \%)$ & $0 \backslash 7(0 \%)$ \\
\hline eaeA & $0 \backslash 12(0 \%)$ & $0 \backslash 6(0 \%)$ & $0 \backslash 7(0 \%)$ \\
\hline $\boldsymbol{a a d A 1}$ & $7 \backslash 12(58.3 \%)$ & $2 \backslash 6(33.3 \%)$ & $0 \backslash 7(0 \%)$ \\
\hline
\end{tabular}




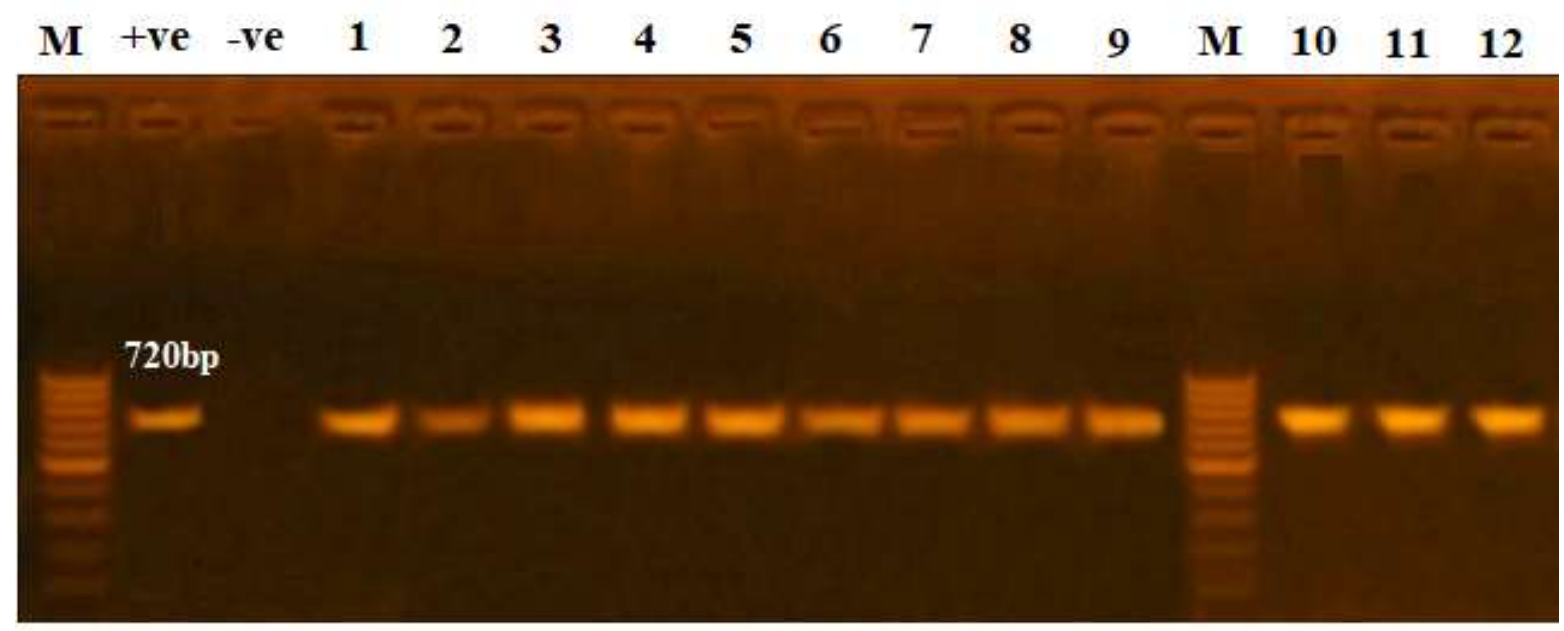

Photo (1): Agarose gel electrophoresis of PCR products after amplification of (PhoA) gene at (720) bp amplified product. All tested isolated from Crows are positive (1-12).

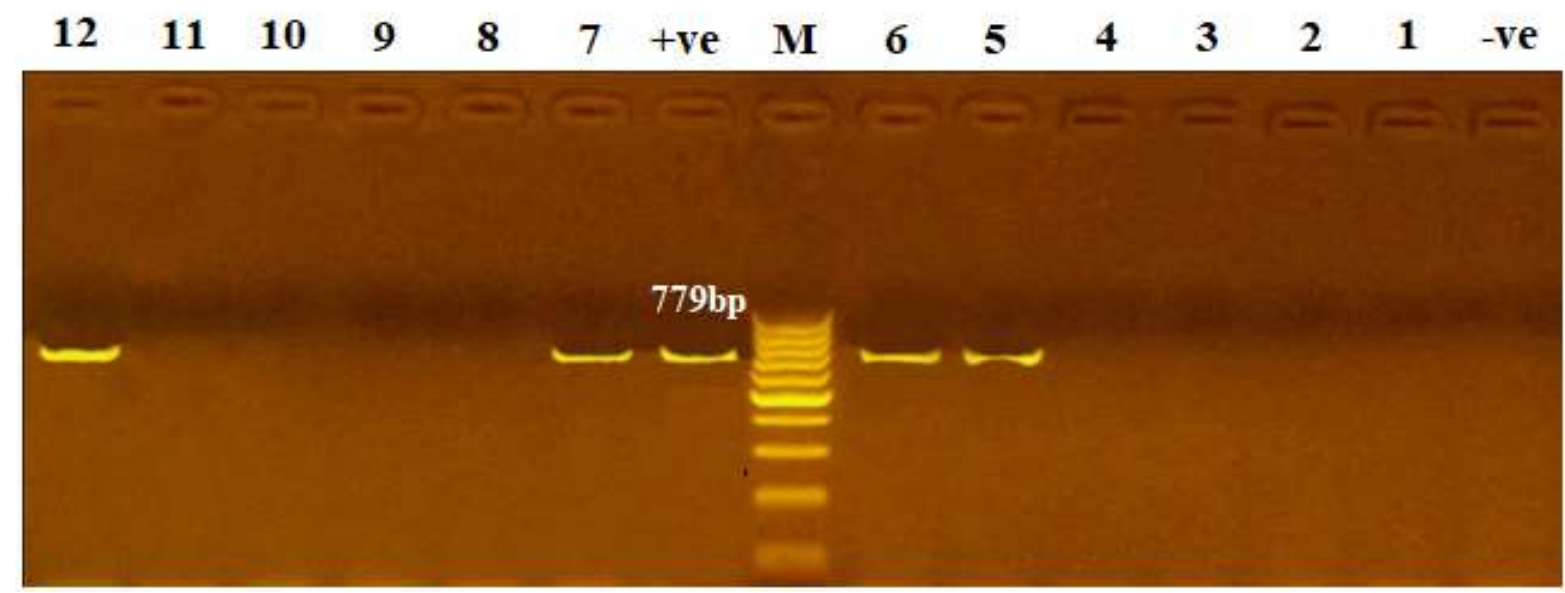

Photo (2): Agarose gel electrophoresis of PCR products after amplification of (sxt2) gene at (779) bp amplified product. Tested isolated from Crows are positive: O78 (2) -O91-O125.

$\begin{array}{lllllllllllllll}M & +v e & -v e & 1 & 2 & 3 & 4 & 5 & 6 & 7 & 8 & 9 & 10 & 11 & 12\end{array}$

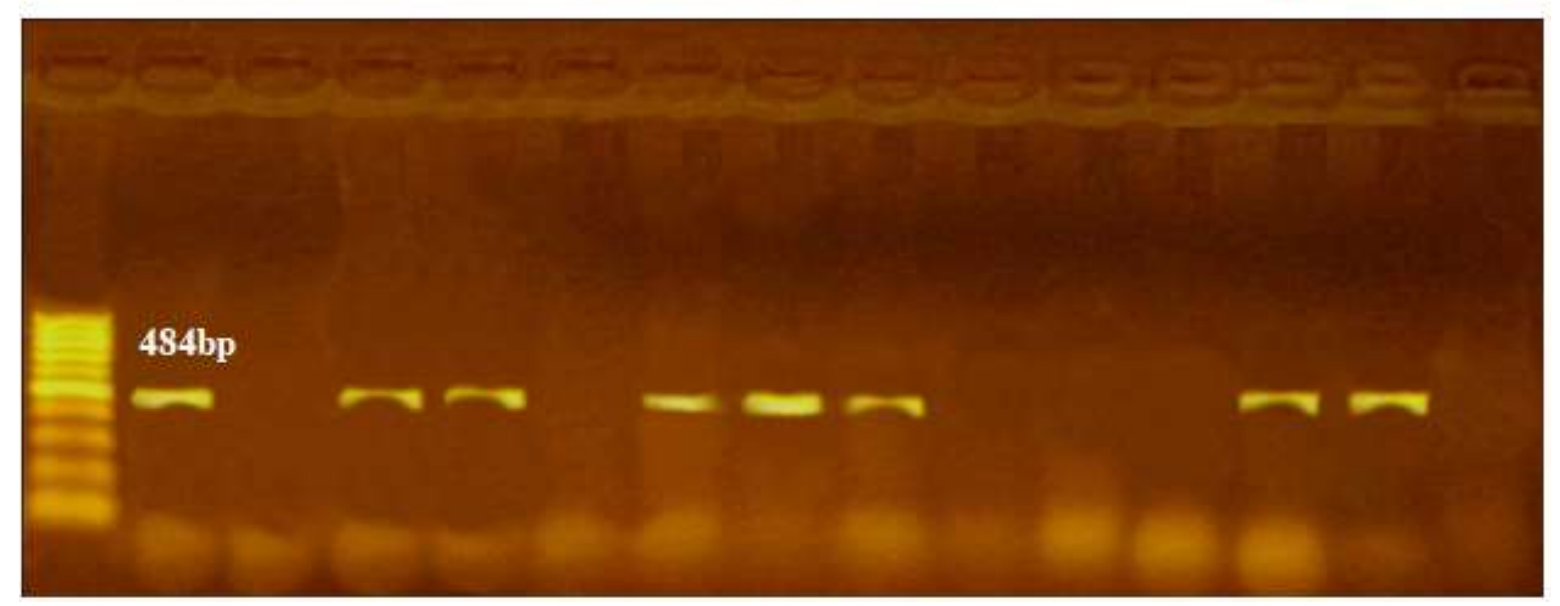

Photo (3): Agarose gel electrophoresis of PCR products after amplification of (aadA1) gene at (484) bp amplified product 7 out of 12. E.coli Crows isolates are positive: O55-O119O158-O78, (2)-O145-O125. 


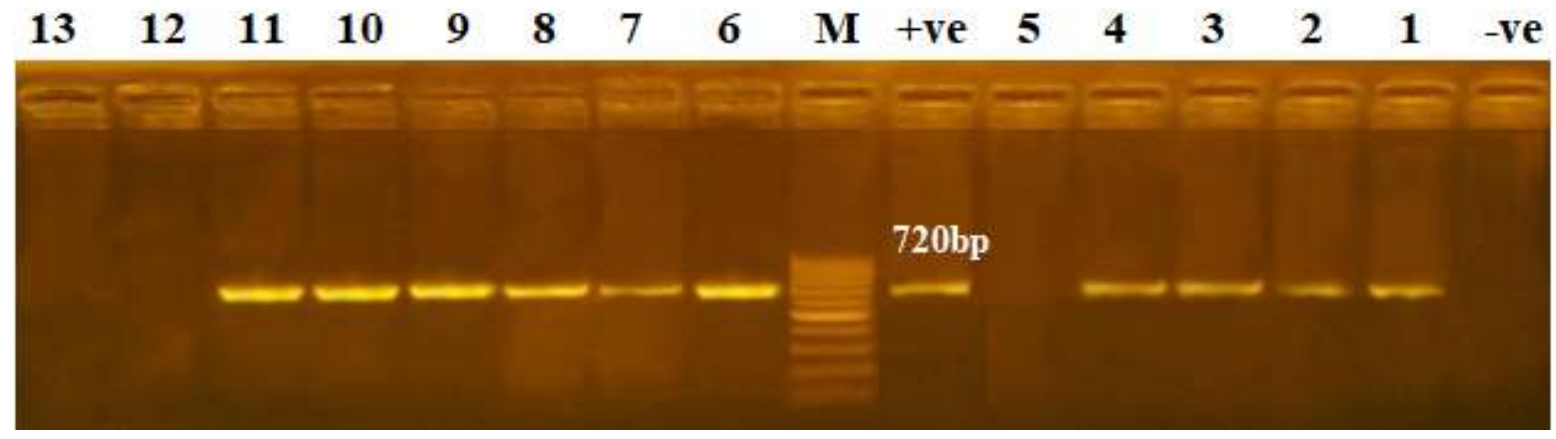

Photo (4): Agarose gel electrophoresis of PCR products after amplification of (PhoA) gene at (720) bp amplified product. All tested isolated from chicken broiler feces are positive (1-7). \{O158- O125 (3) - O78 (2)\} expect (5) \{O78\} negative and four E.coli egret wild bird feces tested isolates are positive (8-11) \{0119-O78- O125-O158\}.while (12-13) negative, \{O44O91\}.

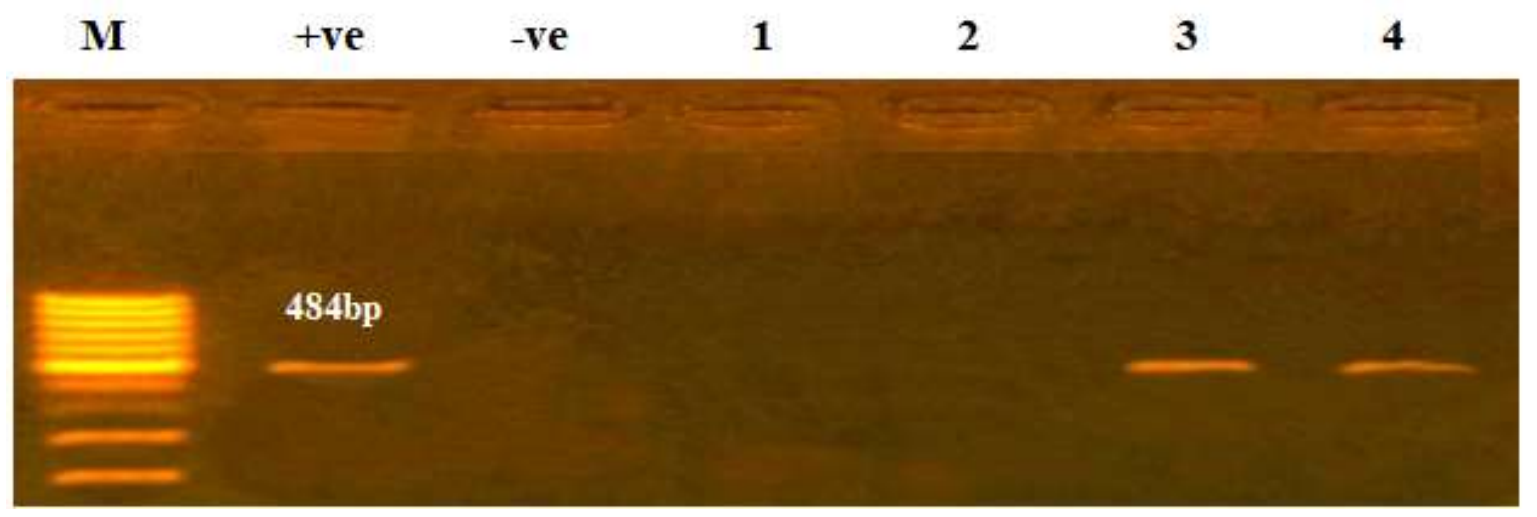

Photo (5): Agarose gel electrophoresis of PCR products after amplification of (aadA1) gene at (484) bp amplified product. Two E.coli isolates from egret wild bird feces (O78-O158) are positive.

\section{DISCUSSION}

Wild birds act as vectors of many diseases not affect only birds, animals but also human (Gharieb et al., 2013; Badouei et al., 2016). The nature of birds, their ability to cover vast distances within a relatively short period of time, their residence near livestock areas, farms, waste disposal sites, and human habitats made them important vectors of some zoonosis (Gioia et al., 2016 and Oravcova, 2016). The data can be used to monitor trends in the occurrence of pathogenic strains, because multiple serogroups are associated with disease, especially $\mathrm{O} 1, \mathrm{O} 2$ and $\mathrm{O} 78$ among many others (Dziva and Stevens, 2008).
In Tables (2), the isolation rate of E.coli was reported to be highly in (crows, Egret wild birds and broiler chicken). Where percentage of the isolation rate was $48 \%$, $28 \%, 40 \%, 20 \%$ and $12 \%$. Respectively. The variation in $E$. coli prevalence rates may be attributed to the species of wild bird examined, localities and bird feeding habits. This result was agree with that described by (Magda et al., 2013 and Aruji et al., 2004) who isolated it from wild birds percentage of $21.6 \%$ and $14.52 \%$ respectively. Concerning examination of broilers, were positive for E. coli. Nearly similar findings were reported by (Ahmed, 2011 and Mona et al., 2013). 
It was observed that several serotypes were recovered from crows (O78, O91, O145 and O125), egret bird feces (O78, O158, O125, O119, O91 and O44) and chicken broiler (O78, O125 and O158). Table (3), These results agreed with (Lin et al., 2011 and Hanaa et al., 2017, El-Sheshtawy et al., 2005 and Maysa et al., 2013) who isolated E. coli from wild birds in Egypt, nearly the same serotypes with a predominance of $\mathrm{O} 78$ have been identified (Reda, 2013).

Table (4), illustrated results of resistance of some testing E.coli isolates recovered from crows feces, egret wild birds feces and chicken broiler feces, against 10 antimicrobial drugs. It is evident that the highest resistance was recorded against Streptomycin (83.4\%, 66.4\% and 42.8\%). These results nearly similar to (Maciel et al., 2017) who Showed that E.coli isolates resistant to streptomycin, doxycycline, and Chloramphenicol. The resistance of microorganisms to antibiotics due to inactivation, drug modification, alteration in metabolic pathway, alteration of target site development of new genes and reduced drug accumulation (Blair et al., 2014 and Pruden et al., 2013).

Studies have reported that the environment imposes its own selection on the population of E.coli following fecal deposition from its primary habitat within the intestine of animals (Jang et al., 2017).

Table (5-6) illustrated the results of (PhoA) gene. Encodes for a hydrolase enzyme which is responsible for removing phosphate groups from molecule. Alkaline phosphatase ( $p h o A)$ gene has been used in PCRs for common $E$. coli strains detection, demonstrating high specificity (hu et al., 2011; Ke Xin et al., 2009).
In the present study, E. coli virulence genes, (stx2) known to be associated with human disease was detected in bird fecal samples. (stx2) was detected more frequently, while none of the isolates from these birds were found to be positive for (st 1 1).which nearly agreed with (Kobayashi et al., 2009, Persad, et al., 2014, Sanches et al., 2017 and Ahmed et al ., 2018).

In contrast, other researchers could not detect (stx1 or stx2) in wild birds. Considering that stx-2 toxin is more toxic than stx-1 and is often associated with wild birds and chicken Similar results were obtained by (Sanches et al., 2017). Found no stx 1 samples among fecal samples from gulls, pigeons, and chickens that were, obtained by (Koochakzadeh et al., 2015 and Ahmed, 2011). Other researchers could not detect (eaeA and hly) gene in wild birds similar results were obtained by (Mona et al., 2013 and Indranil, et al., 2004). Meanwhile these results disagreed with others who found no eaeA and hly gene detected in broiler chickens (Shimaa, 2013).

Antimicrobial resistance has been known as an emerging worldwide problem in both human and veterinary medicine, and antimicrobial use is considered the most important factor for the emergence, selection, and distribution of antimicrobialresistant bacteria (Mohammed et al., 2014). the current study, we also screened the isolates for the presence of selected antimicrobial resistance genes, including those for streptomycin (aadAl), The prevalence of these genes was generally higher in the present study than in previous studies (Dehkordi et al.,2014 ., Marcelino et al., 2019 and Kar et al., 2020 ). And these results differ from (Momtaz et al., 2012). 


\section{CONCLUSION}

These findings show that wild birds, may constitute an environmental carrier of these pathogens representing a source of infection for other birds, livestock, and humans. Wild birds may spread pathogens over a wide range, thus enhancing their carrier role. Further investigations should continue to characterize the antibiotic resistance genes and the epidemiology link between poultry and human. Biosecurity on the poultry farms should be the first line of defense against infectious diseases.

\section{REFERENCE}

Ahmed, K.; Atef, K.; Mohamed, M.; Nada, A. and Doaa, A. (2018): Phenotypic and Genotypic Characterization of Gram negative bacteria Isolated from Birds of Prey (Raptors), SCVMJ, XXIII (2), V (23). Page 31-44.

Ahmed, D.A. (2011): Escherichia Coli Isolated From Broiler Farms with Special References to Virulence Genes of Isolated Strains. Master Veterinary Science Thesis, (Bacteriology) Vet. Med. Zagazig University.

Arnold, K.E.; Williams, N.J. and Bennett, M. (2016): Disperse abroad in the land: The role of wildlife in the dissemination of antimicrobial resistance. Biology Letters, 12, 20160137.

Aruji, Y.; Tamura, K.; Sugita, S. and Adachi, $\quad Y . \quad$ (2004): Intestinal microflora in 45 crows in Ueno Zoo and the in vitro susceptibilities of 29 Escherichia coli isolates to 14 antimicrobial agents. The Journal of Veterinary Medical Science, 66(10): 1283-1286.

Badouei, M.A.; Blackall, P.J.; Koochakzadeh, A.; Nazarpak H.H. and Sepehri, M.A. (2016): Prevalence and clonal distribution of avian Escherichia coli isolates harboring increased serum survival (iss) gene. J Appl Poultry Res 25:6773.

Benskin, C.H.; Wilson, K.; Jones, K. and Hartley, I.R. (2009): Bacterial pathogens in wild birds: a review of the frequency and effects of infection. Cambridge: Philosophical Society, pp 349-373.

Bisi-Johnson, M.A.; Obi, C.L.; Vasaikar, S.D.; Baba, K.A. and Hattori, T. (2011): Molecular basis of virulence in clinical isolates of Escherichia coli and Salmonella species from a tertiary hospital in the Eastern Cape, South Africa. Gut Pathogens 2011, 3:9.

Blair, J.M.A.; Webber, M.A.; Baylay, A.J.; Ogbolu, D.O. and Piddock, L.J.V. (2014): Molecular mechanisms of antibiotic resistance. Nat. Rev. Microbiol., 13: 42-51.

Clark, L. (2003): Review of pathogens of agricultural and human health found in Canada geese. $10^{\text {th }}$ wildlife Damage Management Conference University of Nebraska-Lincoln, P205.

Clinical and Laboratory Standards Institute (CLSI, 2017): Performance standards for antimicrobial susceptibility testing. 27th Informational Supplement Document M100- S27, CLSI, Wayne, Vol. 37: (1).

Dehkordi, F.S.; Yazdani, F.; Mozafari, J. and Valizadeh, Y. (2014): Virulence Factors, Serogroups and Antimicrobial Resistance Properties of Escherichia coli Strains in Fermented Dairy Products. BMC Res. Notes; 7: 217.

Dipineto, L.; Santaniello, A.; Fontanella, M.; Lagos, K.; Fioretti, A. and Menna, L.F. (2006): Presence of Shiga toxin-producing Escherichia coli $\mathrm{O} 157: \mathrm{H} 7$ in living layer hens. Letters in Applied Microbiology 43: 293-295. 
Dziva, F. and Stevens, M.P. (2008): Colibacillosis in poultry. Unraveling the molecular basis of virulence of avian Pathogenic E. coli in their natural hosts. Avian Pathol., 37(4).355366.

El-Sheshtawy, E.A. and Moursi, M.K. (2005): Role of in wild birds in transmission of protozoal and bacterial pathogens to domesticated birds in Ismailia province. J. Egypt. Vet. Med. Assoc., 65: 297-325.

Fogarty, L.R.; Haack, S.K.; Wolcott, M.J. and Whitman, R.L. (2003):

Abundance and characteristics of the recreational water quality indicator bacteria Escherichia coli and enterococci in gull faeces. J Appl Microbiol., 94: 865-878.

Gharieb, A.; AbuEl-ezz, R.M. and Mohamad, R.E. (2013): Prevalence of Enterobacteriacea in wild birds and humans at sharkia province; with special reference to the genetic relationship between $E$. coli and Salmonella isolates determined by protein profile analysis. J. Am. Sci. 9(4): 173-183.

Gomes, A.R.L.; Muniyappa, G.; Krishnappa, V.V.S.; Suryanarayana, S.; Isloor, B. and Prakash, P.G. Huqar (2005): Genotypic characterization of avian Escherichia coli by random amplification of polymorphic DNA. Int. J. Poult. Sci., 4: 378-381.

Guenther, S.; Ewers, C. and Wieler, L.H. (2011): Extended-spectrum betalactamases producing $E$. coli in wildlife, yet another form of environmental pollution Front. Microbiol. 2: 246. 10.

Hanaa, M.F.; Rabab, A. and Dheyazan, M. Al-Qabili (2017): Characterization and zoonotic impact of Shiga toxin producing Escherichia coli in some wild bird species, Vet World. Sep; 10(9): 1118-1128.
Hassan, B.; Olsen, B.; Alam, A.; Akter, L. and Melhus, A. (2015): Dissemination of the multidrugresistant extended-spectrum betalactamase-producing Escherichia coli $\mathrm{O} 25 \mathrm{~b}-\mathrm{ST} 131$ clone and the role of house crow (Corvus splendens) foraging on hospital waste in Bangladesh. Clin. Microbiol. Infect. 21 1000.e1-1000.e4.

Hubalek, Z. (2004): An annotated checklist of pathogenic microorganisms associated with migratory birds. J. Wild. Dis.40, 639-659.

Hu, Q.; Tu, J.; Han, X.; Zhu, Y.; Ding, C. and $Y u, S$. (2011): Development of multiplex PCR assay for rapid detection of Riemerella anatipestifer, Escherichia coli, and Salmonella enterica simultaneously from ducks. J. Microbiol. Methods, (87): 1.64-69. Indranil, S.; Mohd, A.B.; Yoshikazu, N. and Yoshikazu, N. (2004): Investigation of Shiga toxinproducing Escherichia coli in avian species in India. Letters in Applied Microbiology 39(5): 389-94.

Ishii, S.; Hansen, L.; Hicks, R.E. and Sandowsky, M.J. (2007): Beach Sand and sediments are temporal sinks and sources of Escherichia coli in Lake Superior. Sci. Technol., 41, 22032209.

Jamborova, I.; Dolejska, M.; Zurek, L.; Townsend, A.K.; Clark, A.B. and Ellis, J.C. (2017): Plasmid-mediated resistance to cephalosporins and quinolones in Escherichia coli from American crows in the USA. Environ. Microbiol. 19, 2025-2036.

Jang, J.; Hur, H.G.; Sadowsky, M.J.; Byappanahalli, M.N.; Yan, T. and Ishii, S. (2017): Environmental Escherichia coli: ecology and public health implications-a review. J. Appl. Microbiol., 123, 570-581.

Johnson, T.J.; Karjyawasam, S.; Wannemulher, Y.; Mangiamele, P.; Johnson, S.J.; Doetkott, C.; Skyberg , 
J.A.; Lynne, A.M.; Johnson, J.R. and Nolan, L.K. (2007): The genome sequence of avian pathogenic Escherichia coli strain o1: $\mathrm{K} 1: \mathrm{H} 1$ shares strong similarities with human extraintestinal pathogenic $E$. coli genome. J. bacteriol., 189, 32283236.

Kar, H.O.; Wei, C.K.; Jing, Y.Q.; Zi, X.L.; Sathish, A.; Mahathir, H.; Cliff, C.; Kelyn, L.G.S.; Siyao, G.; Moon, Y.F.T.; Joergen, S.; Lee, C.N. and Kyaw, T.A. (2020): Occurance and antimicrobial resistance traits of E.coli from wild birds and rodents in Singapore, international journal environment reaserch and public healthy, 17: 5606.

Keya, S.; Tanner, B.; Marilia, A.; Soares, B.T.; Yizheng, Ma.; Laura, K.M.F.; Jingrang, L.U. and Robert, J.T. (2019): Antibiotic Resistance of $E$. coli Isolated From a Constructed Wetland Dominated by a Crow Roost, With Emphasis on ESBL and AmpC Containing E. coli. Front Microbiol. 10: 1034.

Ke Xin Yu and Kwai Lin Thong (2009): Multiplex PCR for Simultaneous Detection of Virulence Genes in Escherichia coli Malaysian Journal of Science 28 (1): 1-14.

Kobayashi, H.; Kanazaki, M.; Hata, E. and Kubo, M. (2009): Prevalence and Characteristics of eae-and stxPositive Strains of Escherichia coli from Wild Birds in the Immediate Environment of Tokyo Bay, applied and environment microlo, $\operatorname{vol}(75), \mathrm{n}$ (1) : 292-295.

Koneman, E.W.; Allen, S.D.; Janda, W.M.; Schreckenberger, P.C. and Winn, W.C. (1997): Diagnostic Microbiology. $5^{\text {th }}$ Ed. Chapter 1.Philadelphia. Newyork.

Koochakzadeh, A.; Askari, B.M.; Zahraei, S.T.; Aghasharif, S.; Soltani, M. and Ehsan, M.R. (2015): Prevalence of Shiga toxin-producing and enteropathogenic Escherichia coli in wild and pet birds in Iran. Braz. J. Poult. Sci., 17(4): 445-450.

Lee, M.D. and Nolan, K.L. (2008): A laboratory manual for the isolation and identification of avian pathogen In: Zavala, L.D., Swayne, D.E., John, R.C., Mark, W.G Wood, J., Pearson, J.E. and Reed, W.M, editors. Editorial, Board for the American Association of Avian Pathologists. 5 th ed., Ch. 3. American Association, Colibacillosis. P10-16.

Lee, G.Y.; Jang, H.I.; Hwang, I.G. and Rhee, M.S. (2009): Prevalence and classification of Pathogenic Escherichia coli isolated from fresh beef, poultry, and pork in Korea. Int. J. Food Microbial, 134(3): 196-200

Lin, A.; Nguyen, L.; Lee, T.; Clotilde, L.M.; Kase, J.A.; Son, I.; Carter, J.M. and Lauzon, C.R. (2011): Rapid $O$ serogrouping of the ten most clinically relevant STECs by Luminexmicrobead-based suspension array. J. Microbiol. Methods, 87 (1): 105-110.

Lisa, K.N.; Barnes, J.; Jean-Pierre, V.; Tashseen, A.A. and Catherine, M.L. (2013): Colibacillosis in diseases of poultry, 13th Edition.

Maciel, J.F.; Matter, L.B.; Trindade, M.M.; Camillo, G.; Lovato, M.; De Ávila Botton, S. and Castagna de Vargas, A. (2017): Virulence factors and antimicrobial susceptibility profile of extra intestinal Escherichia coli isolated from an avian coli septicemia outbreak Microbial Volume 103, Pages 119-122.

Magda, A.M.A.; Ali, M.N.M.; Maysa, A.I.A.; Amin, A.H.A.; Rasha, M.M.A. and Rehab, E.M. (2013): Prevalence of Enterobacteriacea in wild birds and humans at Sharkia proviance, with special reference to the genetic relationship between E.coli and salmonella isolates determined by 
protein profile analysis. Journal of American Science 2013; 9 (4).

Marcelino, V.; Wille, M.; Hurt, A.; Gonz. ález-Acuña, D.; Klaassen, M.; Eden, J.S.; Shi, M.; Iredell, J.; Sorrell, T. and Holmes, E. (2019): Metatranscriptomics reveals a diverse antibiotic resistance gene pool in avian microbiomes.BMC Biol.: 17, 31:1-31:11.

Maysa, A.A.; Merwad, A.M. and Rehab, E.M. (2013): Prevalence of zoonotic Escherichia coli and Salmonellae in wild birds and humans in Egypt with emphasis on RAPD-PCR fingerprinting of E.coli Global Veterinarial 11(6): 781-788.

Mbanga, J. and Nyararai, Y.O. (2015): Virulence gene profiles of avian pathogenic Escherichia coli isolated from chickens with colibacillosis in Bulawayo, Zimbabwe. J Vet. Res.; 82(1): 850.

Middleton, J.R.; Fales, W.H.; Luby, C.D.; Landsay, Oaks, J.; Susan, S.; Kinyon, J.M.; Wu, C.C.; Maddox, C.W. and Hartmann, F. (2005): Surveillance of Staphylococcus aureus in veterinary teaching hospitals. J. Clin. Microbiol, 43(6): 2916-2919.

Mohammed, Y.; Shobrak, A. and AboAmer, E. (2014): Role of wild birds as carriers of multi-drug resistant Escherichia coli and Escherichia vulneris, Braz. J. Microbiol., vol. 45 no.4 São Paulo Oct. /Dec. 2014.

Momtaz1, H.; Rahimi, E. and Moshkelani, S. (2012): Molecular detection of antimicrobial resistance genes in $E$. coli isolated from slaughtered commercial chickens in Iran. Veterinarni Medicina, 57, 2012 (4): 193-197.

Mona, A.A.; Fatma, M.Y. and Abdel Rahman, A.G. (2013): Differentiation between E. colis Strains Causing Diarrhea in Broiler
Chicken by Using Multiplex PCR.

Egypt. J. Vet. Sci. Vol. 44, pp. 21-36.

Moore, J.E.; Gilpin, D.; Crothers, E.;

Canney, A.; Kaneko, A. and Matsuda, M. (2002): Occurrence of Campylobacter spp. And Cryptosporidium spp. in seagulls (Larus spp.). Vector Borne Zoonotic Dis 2: 111-114.

Oteo, J.; Mencía, A.; Bautista, V.; Pastor, N.; Lara, N.; González-González, F.; García-Peña, F.J. and Campos, J. (2018): Colonization with Enterobacteriaceae-Producing ESBLs, AmpCs, and OXA-48 in Wild Avian Species, Spain 20152016. Microb Drug Resist. Sep; 24(7): 932-938.

Persad, A.K. and LeJeune, J.T. (2014): Animal reservoirs of Shiga toxinproducing E. coli. Microbiol. Spectr., 2(4): EHEC-0027-2014.

Piva, I.C.; Pereira, A.L.; Ferraz, L.R.; Silva, R.S.N.; Vieira, A.C.; Blanco, J.E.; Blanco, M.; Blanco, J. and Giugliano, L.G. (2003): Virulence Markers of Entero aggregative Escherichia coli Isolated from Children and Adults with Diarrhea in Brasília, Brazil. J.clinical microbiology, p. 1827-1832.

Pruden, A.; Larsson, D.J.; Amézquita, A.; Collignon, P.; Brandt, K.K.; Graham, D.W.; Lazorchak, J.M.; Suzuki, S.; Silley, P. and Snape, J.R. (2013): Management options for reducing the release of antibiotics and antibiotic resistance genes to the environment. Environmental Health Perspectives (Online), 121(8): 878.

Quinn, P.J.; Carter, M.E.; Markey, B.K.; Donnoly, W.J. and Leonard, F.C. (2002): Veterinary microbiology and microbial disease.166-1117 Osney Mead, Oxford first LTd, Registered at the United Kingdom.

Randall, L.P.; Cooles, S.W.; Osborn, M.K.; Piddock, L.J.V. and Woodward, M.J. (2004): Antibiotic 
resistance genes, integrons and multiple antibiotic resistance in thirty-five serotypes of Salmonella Enterica isolated from humans and animals in the UK. Journal of Antimicrobial Chemotherapy. 53, 208-216.

Reda, M.L. (2013): Studies on antibiotic resistance of Escherichia coli isolated from poultry and children. Suez Canal Vet. Med. J.; 18(2): 2740

Sanches, L.A.; Gomes, M.D.S.; Teixeira, R.H.F.; Cunha, M.P.V.; Oliveira, M.G.X. and Vieira, M.A.M. (2017): Captive wild birds as reservoirs of enteropathogenic E. coli (EPEC) and Shiga-toxin producing E. coli (STEC). Braz J Microbiol; 48(4): 760-763.

Shimaa, H.A.M. (2013): Some Advanced Studies on avian pathogenic E.coli in broiler chickens at Sharkia Governorate. M.V.Sc. Thesis, Fac. Vet. Med., Zagazig Univ.

Waldenström, J.; Ottvall, R.; Hasselquist, D.; Harrington, CS. and Olsen, B. (2003): Avian reservoirs and zoonotic potential of the emerging pathogen Helicobacter canadensis. Appl Environ Microbiol 69: 75237526. 


\section{متلازمة الإسهال في دجاج التسمين وبعض الطيور البرية التي يسببها الميكروب القولوني غادة عمر الدمرد/ش ، فاطمة عامر ، هبة رشدي}

E-mail: roshdy2019 @yahoo.com Assiut University web-site: www.aun.edu.eg

الميكروب القولوني هو بكتيريا سالبة الجر ام ، وهي تعيش في الأمعاء بشكل طبيعي ، إلا أن بعض السلالات بسبب جينات

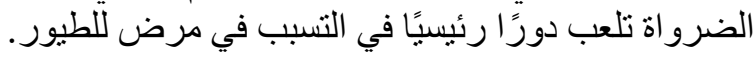

في هذه الدر اسة نم جمع ـ 10 عينة براز وتم فحص العينات بكترلوجيا للميكروب القولوني من (الغربان ، و البلثون البري

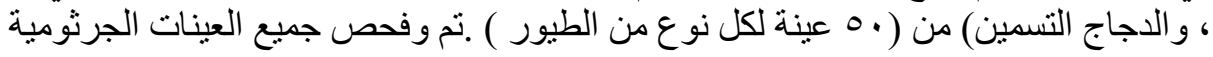

و واظهرت النتائج الميكروب القولوني وكانت تسجيل نسبة عزل بكتبريا الميكروب القولوني مرتفعة في محافظة الفيوم

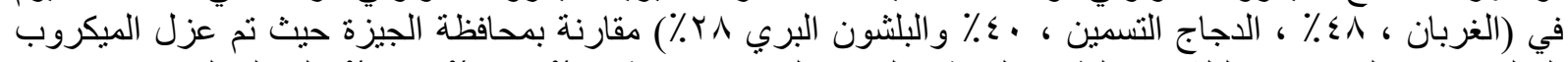

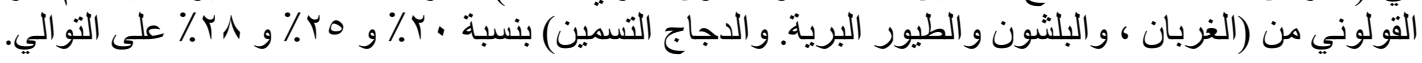

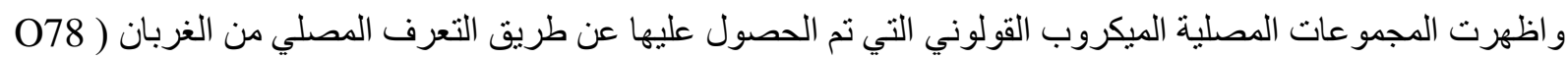

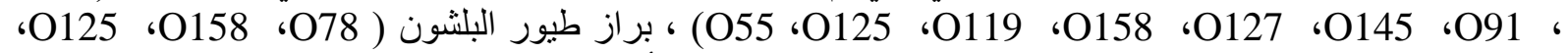

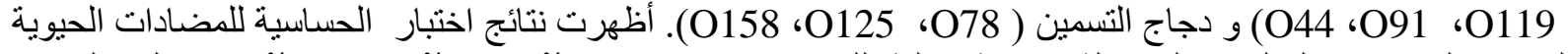

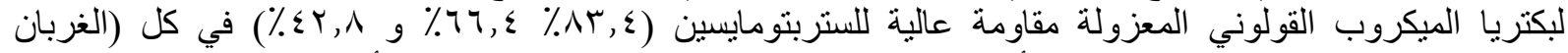

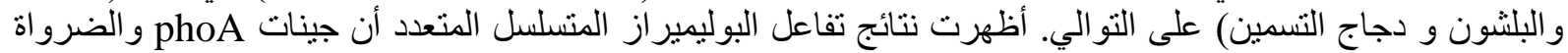

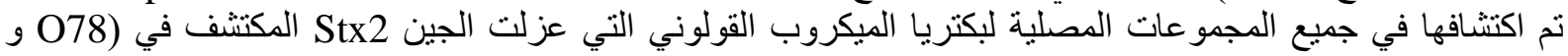

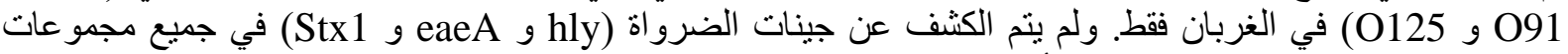

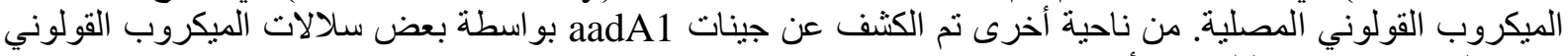
(7من الغربان و r من البلشون الأبيض). 